\title{
Corporate Social Performance: A multi-Stakeholder Analysis of Indonesian Energy Companies' Sustainability Report
}

\author{
Amelia Kurniawati, TMA Ari Samadhi, Iwan Inrawan Wiratmadja, Indryati Sunaryo, Rayinda \\ Pramuditya Soesanto, and Fadel Muhammad
}

\begin{abstract}
Energy companies in Indonesia hold an important role in the Indonesian economy. Related to their important roles and responsibility in maintaining corporate sustainability in managing the business that related to non-renewable resources, energy companies in Indonesia publish their Sustainability Report as their commitment to providing information for stakeholders on corporate governance, performance, and strategy. As a part of performance measurement, energy companies in Indonesia also consider the importance of multi-stakeholder perspective in the making of a sustainability report. Performance measurement which involves multi-stakeholder is known as Corporate Social Performance. The purpose of this research is to develop the CSP measurement indicators from the multi-stakeholder perspective, to identify the most and the least discussed indicators in the sustainability reports of seven energy companies in Indonesia from the latest three years reports, and then to be compared with sustainability reports from two automotive companies and two cement companies. The result of this research are developing CSP measurement consisting of 38 indicators that categorized into six categories, which are customer focused, community focused, shareholder focused, supplier focused, an environment focused, and employee focused. The most discussed indicators in Sustainability Reports of energy companies in Indonesia are in environment focused category and the least discussed indicators are in supplier focused category.
\end{abstract}

Index Terms-Corporate social performance, energy company, sustainability, multi-stakeholder perspective.

\section{INTRODUCTION}

Energy companies in Indonesia hold an important role in the Indonesian economy. In 2016, energy companies in Indonesia contributed to the Non-Tax State revenues from oil and gas around Rp78.6 trillion, the Tax State Revenues from oil and gas around Rp41.4 trillion, the distribution of

Manuscript received March 27, 2018; revised May 12.

Amelia Kurniawati is with the Department of Industrial Engineering, Bandung Institute of Technology, Bandung, Indonesia and also with the Department of Industrial Engineering, Telkom University, Bandung, Indonesia (e-mail: amelia.kurniawati@gmail.com).

TMA Ari Samadhi, Iwan Inrawan Wiratmadja, Indryati Sunaryo, and Rayinda Pramuditya Soesanto are with the Department of Industrial Engineering, Bandung Institute of Technology, Bandung, Indonesia (e-mail: asamadhi@mail.ti.itb.ac.id, iwan@lspitb.org, rya_ryo@yahoo.com, raysoesanto@telkomuniversity.ac.id).

Fadel Muhammad is with the Department of Information System, Telkom University, Bandung, Indonesia (e-mail: fadelmuhammad24@gmail.com).
Government energy subsidies of Rp182.6 trillion to the energy sector State Owned Enterprises [1], and also the responsibility of ease access to affordable and cleaner energy, as an example, Indonesia's electrification ratio recently stood at $84.1 \%$ in January 2015 [2]. Related to those important roles, energy companies in Indonesia publish their Sustainability Report annually complementary to their Annual Report as their commitment to providing information for stakeholder on corporate governance, performance, and strategy of maintaining corporate sustainability in managing the business that related to non-renewable resources.

Corporate sustainability refers to company voluntary activities demonstrating the inclusion of social and environmental concerns in business operations and in interactions with stakeholders [3]. Corporate sustainability is considered as the ultimate goal, with corporate social responsibility as an intermediate stage where the companies try to balance the triple bottom line: profit (economic), people (social), and the planet (environmental) [4], [5]. Van Marrewijk [6] stated that organizational performance in the economic, environmental, and social domain which involves multi-stakeholder has long term impact.

The multi-stakeholder perspective of organizational performance, especially for energy companies, is important. It is because an industry company does not operate in isolation but interacts with multi-stakeholder [7]. Because of that, performance measurement for the industry has evolved from time to time. At first, industry performance is measured based on its productivity, and then expanded to financial performance, and evolved to involve multi-stakeholder [8]. Performance that is related to multi-stakeholder becomes an important part in organizational outcome [7]. Performance measurement which involves multi-stakeholder is known as Corporate Social Performance (CSP).

Energy companies in Indonesia develop the sustainability report based on topics or aspects that are significant to companies' sustainability and stakeholders. The sustainability report of energy companies in Indonesia has complied with Sustainability Reporting Guideline G4 that was published by Global Reporting Initiative. However, 7 energy companies in Indonesia determine different material aspects and priority topics to be presented in their sustainability report.

This research aims to develop the CSP measurement indicators from a multi-stakeholder perspective. The developed CSP measurement indicators then compared to the content of the sustainability report of energy companies in Indonesia. 


\section{MethodOLOGY}

The first step in this research is to identify the purpose of the research. The purpose of this research is to develop the CSP measurement indicators from the multi-stakeholder perspective and to identify the most and the least discussed indicators in the sustainability report of energy companies in Indonesia. After the purpose is established, the second step is a literature review. The literature that supports this research is related to the CSP measurement and indicators.

The third step is gathering sustainability reports, which are the secondary data used in this research. The sustainability reports used in this research are published by the energy companies and has open access from respective companies. The fourth step is measurement model development. The indicators in this measurement model are mainly elaborated from Ducassy and Montadrau [9], Orlitzky et al. [10] and Dočekalova [11]. After the model is developed, the fifth step is data collection. The data are gathered from sustainability reports of seven energy companies from the latest three years reports.

The seven energy companies consist of 3 state-owned enterprise (SOE), 2 subsidiaries of SOE and 2 private companies. All of the three state-owned companies have been operating in Indonesia for more than 22 years, and the rest four companies are listed as public company for more than 10 years. Most of them have been anually publishing sustainability report at least for more than 5 years.

After data gathering, the sixth step is data processing. In this step, the content of sustainability reports is reviewed and then matched with the CSP indicators developed from the literature review. The seventh step is analyzing the result. In this step, the most and the least discussed indicators in the sustainability report of energy companies in Indonesia are identified. The analysis is done for each dimension. Identification of the most discussed indicators can provide insight related to which stakeholder's needs that the companies most concern about. Identification of the least discussed indicators can help the companies to improve the quality of their relationship with the least concerned stakeholder's needs. The harmony in the relationship between company and their stakeholders will lead to sustainability. In the analysis, the result from energy companies are also compared with sustainability reports from automotive and cement companies. The automotive and cement companies are chosen for comparison because both represent manufacture industry, same as the energy companies. The cement companies are listed as public company for more than 22 years. The sustainability reports of the automotive and cement companies used in this research are opened for public. The last step in this research is formulating the conclusion of this research and suggest the further research that can be done.

\section{A. Corporate Social Performance}

Corporate social performance is defined as the measurement of the organizational outcome in environmental, social, and governance domains with respect to multiple stakeholders such as employees, local communities, or shareholders [10]. CSP reflects company's responsibilities to multiple stakeholders, such as employees and the community at large, in addition to its traditional responsibilities to economic shareholders. The stakeholders involved with a company are owners or shareholders, employees, customers, and suppliers or society [12]. In this research, CSP is defined as the measurement of organizational outcome in social, environmental, economic, and governance domains by considering multiple stakeholders, both internal stakeholders such as employees, and shareholders, as well as external stakeholders such as customers, suppliers, and society [5], [10], [12], [13].

\section{B. Corporate Social Performance Indicator}

CSP indicators have formulated by various organizations such as French Corporate Information Center (CFIE) [9], Kinder, Lydenberg and Domini (KLD) [13], and Sustainable Investment Research International (SiRi) [10]. CSP indicators for a company are adapted to the type of stakeholders involved with the company. A stakeholder of a system is defined as an individual, an object, or a group that is directly affected by the performance of the system and can have an influence in creating its future [15].

To measure CSP, Dočekalova [11] develops 10 indicators, Ducassy and Montadrau [9] uses 21 headings from French Corporate Information Center (CFIE), and Orlitzky et al. [10] use six main indicator categories from Sustainable Investment Research International (SiRi) which has 28 indicators. The indicators from Dočekalova [11], Ducassy and Montadrau [9] and Orlitzky et al. [10] are elaborated in this research. By elaborating these indicators, a more comprehensive set of indicators is developed. In this research, the indicators are categorized into six categories according to Orlitzky et al [10], which are customer focused, community focused, shareholder focused, supplier focused, an environment focused, and employee focused.

Customer focused is defined as an overview related to company's commitment to maintaining product quality, achieving high levels of customer satisfaction, and implementing ethical marketing practices. The indicators in this category are as follow.

- Quality of management systems

- Customer satisfaction

- Competitive practices

- Marketing practices

- Health and safety of customers

Community focused is defined as a description of company's consideration of the needs, interests, and rights of communities affected by the operations of the company. The indicators in this category are as follow.

- Stakeholder consultation processes

- Impact on the development of local communities

- Community enterprises and patronage

- Lobbying activities

- Compliance with international law

Shareholder focused is defined as a description of the independence of directors, the existence, and composition of board-specific committees, as well as other aspects of good corporate governance. The indicators in this category are as follow.

- Independence of directors 
- Reporting process

- Compensation and remuneration schemes

- Voting rights

- Anti-takeover devices

- Rollout of CSR in terms of organization

- Awareness and training for CSR

Supplier focused is defined as an overview of the company's commitment toward worldwide fair labor standards and freedom of association. The indicators in this category are as follow.

- Outsourcing policy

- Code of conduct for contractors

- Monitoring of subcontractors and company suppliers

- Involvement in labor rights violations of firm contractors

- Relations with subcontractors and suppliers

Environment-focused is defined as an overview related to company's commitment to creating an appropriate environment management system, increase the efficiency in the use of resources and energy, as well as preventing the harm to the environment. The indicators in this category are as follow.

- Resource consumption

- Energy consumption reduction efforts

- Factoring in ecosystems

- Discharge, pollution, and waste management

- Assessment and compliance procedures

- Environmental management organization and training

- Environmental risk management and prevention

Employee focused is defined as an overview of the company's commitment toward the social problems associated with employees, especially the problem of health and safety, diversity, and employee involvement. The indicators in this category are as follow.

- Work time organization and management

- Workforce management

- Payroll and compensation

- Hygiene and safety conditions

- Industrial relations

- Employee involvement/participation

- Equality and non-discrimination

- Training

- Labor Relations

\section{RESULT AND DISCUSSION}

\section{A. Reviews on Indicator in Each Category}

In customer focused category, almost all of the indicators are discussed in the sustainability reports of the 7 energy companies in Indonesia, except health and safety of customers that only discussed in 2 energy companies' sustainability reports. The material aspects of sustainability reports shown that the awareness of the energy companies in Indonesia related to health and safety issues is still focused on the companies' internal scope. Based on the CSP indicators from the literature, health and safety issues of the customer also need to be noticed, especially at the moments when the customer interacts with the companies' product.
TABLE I: NUMBER OF INDICATORS DISCUSSED OF CUSTOMER-FOCUSED IN 21 SUSTAINABILITY REPORTS

\begin{tabular}{lll}
\hline \hline & $\begin{array}{l}\text { Number of } \\
\text { Sustainability } \\
\text { Reports }\end{array}$ & Percentage \\
& 20 & $95 \%$ \\
\hline Quality of management system & 16 & $76 \%$ \\
Customer satisfaction & 14 & $67 \%$ \\
Competitive practices & 20 & $95 \%$ \\
Marketing practices & 4 & $19 \%$ \\
Health and safety of customers & & \\
\hline \hline
\end{tabular}

In community focused category, almost all of the indicators are discussed in the sustainability reports of the energy companies in Indonesia, except lobbying activities. Generally, lobbying activities are informally done by the energy companies in Indonesia so they are not listed in the sustainability reports. The sustainability reports show that the companies understand that good relation among the energy companies with the local communities is an important factors for the companies' sustainability.

In shareholder focused category, the most widely discussed indicator is reporting process. Meanwhile, the least discussed indicators are voting rights and anti-takeover devices. Those two indicators were never discussed in the sustainability reports of energy companies in Indonesia.

TABLE II: NUMBER OF INDICATORS DISCUSSED OF COMMUNITY-FOCUSED IN 21 SUSTAINABILITY REPORTS

\begin{tabular}{lll}
\hline \hline & $\begin{array}{l}\text { Number of } \\
\text { Sustainability } \\
\text { Reports }\end{array}$ & Percentage \\
\hline $\begin{array}{l}\text { Stakeholder consultation } \\
\text { processes }\end{array}$ & 18 & $86 \%$ \\
$\begin{array}{l}\text { Impact on the development of } \\
\text { local communities }\end{array}$ & 19 & $90 \%$ \\
$\begin{array}{l}\text { Community enterprises and } \\
\text { patronage }\end{array}$ & 15 & $71 \%$ \\
$\begin{array}{l}\text { Lobbying activities } \\
\text { Compliance with international } \\
\text { law }\end{array}$ & 0 & $0 \%$ \\
\hline \hline
\end{tabular}

In supplier focused category, the most widely discussed indicator is monitoring of subcontractors and company suppliers. Meanwhile, the least discussed indicators are outsorcing policy and involvement in labor rights violations of firm contractors.

TABLE III: NUMBER OF INDICATORS DISCUSSED OF SHAREHOLDER-FOCUSED IN 21 SUSTAINABILITY REPORTS

\begin{tabular}{lll}
\hline Indicators & $\begin{array}{l}\text { Number of } \\
\text { Sustainability } \\
\text { Reports }\end{array}$ & Percentage \\
\hline $\begin{array}{l}\text { Independence of directors } \\
\begin{array}{l}\text { Reporting process } \\
\text { Compensation and }\end{array}\end{array}$ & 6 & $29 \%$ \\
remuneration schemes & 10 & $100 \%$ \\
Voting rights & 0 & $48 \%$ \\
$\begin{array}{l}\text { Anti-takeover devices } \\
\text { Rollout of CSR in terms of }\end{array}$ & 0 & $0 \%$ \\
$\begin{array}{l}\text { organization } \\
\text { Awareness and training for CSR }\end{array}$ & 8 & $0 \%$ \\
\hline \hline
\end{tabular}

In general, companies in Indonesia do not intervene the industrial relation between the firm contractors and their labor since it is the responsibility and has been regulated by Ministry of Labor. 
TABLE IV: NUMBER OF INDICATORS DISCUSSED OF SUPPLIER-FOCUSED IN 21 SUSTAINABILITY REPORTS

\begin{tabular}{|c|c|c|}
\hline Indicators & $\begin{array}{l}\text { Number of } \\
\text { Sustainability } \\
\text { Reports }\end{array}$ & Percentage \\
\hline Outsourcing policy & 1 & $5 \%$ \\
\hline Code of conduct for contractors & 7 & $33 \%$ \\
\hline $\begin{array}{l}\text { Monitoring of subcontractors and } \\
\text { company suppliers }\end{array}$ & 12 & $57 \%$ \\
\hline $\begin{array}{l}\text { Involvement in labor rights } \\
\text { violations of firm contractors }\end{array}$ & 1 & $5 \%$ \\
\hline $\begin{array}{l}\text { Relations with subcontractors and } \\
\text { suppliers }\end{array}$ & 10 & $48 \%$ \\
\hline
\end{tabular}

However, for the next sustainability report, it would be better if the companies discuss more about the policy related to the supplier, especially the policy that controlled by the companies.

In environment focused category, all the indicators are widely discussed in the sustainability of energy companies in Indonesia. This reflects the awareness of energy companies in making sustainability report focuses on aspects of the environment. In employee focused category, almost all the indicators are discussed in the sustainability reports of energy companies in Indonesia, except work time organization and management that only discussed in 3 sustainability reports and industrial relation indicator that only discussed in 9 sustainability reports.

TABLE V: NUMBER OF INDICATORS DISCUSSED OF ENVIRONMENT-FOCUSED IN 21 SUSTAINABILITY REPORTS

\begin{tabular}{lll}
\hline \hline & $\begin{array}{l}\text { Number of } \\
\text { Sustainability } \\
\text { Reports }\end{array}$ & Percentage \\
\hline $\begin{array}{l}\text { Resource consumption } \\
\begin{array}{l}\text { Energy consumption reduction } \\
\text { efforts }\end{array}\end{array}$ & 15 & $71 \%$ \\
$\begin{array}{l}\text { Factoring in ecosystems } \\
\begin{array}{l}\text { Discharge, pollution, and waste } \\
\text { management }\end{array}\end{array}$ & 19 & $95 \%$ \\
$\begin{array}{l}\text { Assessment and compliance } \\
\text { procedures }\end{array}$ & 21 & $90 \%$ \\
$\begin{array}{l}\text { Environmental management } \\
\text { organization and training }\end{array}$ & 18 & $95 \%$ \\
$\begin{array}{l}\text { Environmental risk management } \\
\text { and prevention }\end{array}$ & 18 & $100 \%$ \\
\hline \hline
\end{tabular}

On energy companies in Indonesia, things related to the indicators of employee focused category generally have been managed and not a point at issue in the contract with their workers.

TABLE VI: NUMBER OF INDICATORS DISCUSSED OF EMPLOYEE-FOCUSED IN 21 SUSTAINABILITY REPORTS

\begin{tabular}{lll}
\hline \hline & $\begin{array}{l}\text { Number of } \\
\text { Sustainability } \\
\text { Reports }\end{array}$ & Percentage \\
\hline Work time organization and & 3 & $14 \%$ \\
management & 21 & $100 \%$ \\
Workforce management & 13 & $62 \%$ \\
Payroll and compensation & 18 & $86 \%$ \\
Hygiene and safety conditions & 9 & $43 \%$ \\
Industrial relations & 18 & $86 \%$ \\
Employee & 18 & $86 \%$ \\
involvement/participation & 21 & $100 \%$ \\
Equality and non-discrimination & 18 & $86 \%$ \\
Training & & \\
Labor relations & & \\
\hline \hline
\end{tabular}

\section{B. Reviews on Energy Companies}

In general, environment-focused category becomes the most frequently discussed in the sustainability reports of energy companies in Indonesia with the percentage value of $89 \%$. And supplier-focused category becomes the most rarely discussed in the sustainability reports of energy companies in Indonesia with the percentage value of $30 \%$. Ordered by rank from the most to the least discussed, the categories are environment focused, employee focused, customer focused, community focused, shareholder focused, and supplier focused.

TABLE VII: AVERAGE OF INDICATORS DisCUSSED IN 21 SUSTAINABILITY

\begin{tabular}{lll}
\multicolumn{2}{c}{ REPORTS } \\
\hline \hline Categories & Average indicators discussed & Percentage \\
\hline Customer-focused & 15 & $70 \%$ \\
Community-focused & 14 & $67 \%$ \\
Shareholder-focused & 9 & $41 \%$ \\
Supplier-focused & 6 & $30 \%$ \\
Environment-focused & 19 & $89 \%$ \\
Employee-focused & 15 & $74 \%$ \\
\hline \hline
\end{tabular}

According to the sustainability reports that issued by energy companies in Indonesia, the most number of indicators discussed in a report are 30 indicators of 38 CSP indicators. Meanwhile, the fewest number of indicators discussed in a report are 9 indicators of 38 CSP indicators.

In determining the material aspects that will be listed in a sustainability report, energy companies in Indonesia currently refer to the Global Reporting Initiative Guideline G4 (GRI-G4) with different sector disclosures \& core options and the result of discussion with their stakeholders.

With an average number of indicators that are discussed in the sustainability reports of Indonesian energy companies are 24 indicators, correspondence between Corporate Social Performance indicators and focus on material aspects of the energy companies in Indonesia that need to be included in the sustainability report by $63 \%$.

Based on observations in the sustainability reports of Indonesian energy companies, there are findings related to production resources indicator that covered in 17 of 21 sustainability reports. The coverage of production resources includes the availability assurance of the main resources and alternative resources required to ensure the sustainability of business activities. The production resources indicator is not covered by the current CSP Indicators. However, the CSP indicators that developed in this study are general to a wide range of industries. The use production resources as a CSP indicator need to be customized for some industries.

This study is done based on secondary data, which are the companies' report. Because of that, the data which are processed in this study are limited to the reported data. The result of this study can be improve by doing more exploration directly to the company to confirm the secondary data and to reveal the unreported situation. The interaction with the companies also can enrich the CSP indicators so it can be more contextual.

\section{Comparison with Other Industries}

For comparison to the energy companies in Indonesia, this research will use the sustainability reports of two automotive 
companies and two cement companies in Indonesia.

\section{Automotive Industry Companies}

In customer focused category, all indicators are discussed in the sustainability reports of 2 automotive companies in Indonesia, except health and safety of customers which is only discussed by one automotive company.

In community focused category, the most widely discussed indicators in the sustainability of energy companies in Indonesia are impacted on the development of local communities, community enterprises and patronage, and compliance with international law. Meanwhile, the least discussed indicator is lobbying activities. Similar with Indonesian Energy Companies, lobbying activities informally done by Indonesian automotive industry so they are not listed in the sustainability reports.

In shareholder focused category, the most widely discussed indicators are the rollout of CSR in terms of organization, code of conduct for contractors, and monitoring of subcontractors and company suppliers. Meanwhile, the least discussed indicators are voting rights and anti-takeover devices. Those two indicators were also never discussed in the sustainability reports of automotive companies in Indonesia.

In supplier focused category, the least discussed indicator is involvement in labor rights violations of firm contractors. The outsourcing policy indicator is only discussed by one automotive company in Indonesia. The other two indicators are discussed by both companies.

In environment focused category, almost all indicators are widely discussed in the sustainability of energy companies in Indonesia. This reflects the similar awareness between Indonesian automotive and energy companies in making sustainability reports that focus on aspects of the environment.

In employee focused category, the most widely discussed indicator is training. Other indicators are only discussed by one automotive company in Indonesia.

In general, sustainability reports of energy companies and automotive companies in Indonesia have the similar focus on customer focused, community focused, and environment focused categories.

\section{E. Cement Industry Companies}

In customer focused category, all indicators are discussed in the sustainability reports of 2 cement companies in Indonesia, except health and safety of customers.

In community focused category, all indicators are discussed in the sustainability reports of cement companies in Indonesia, except lobbying activities. Similar with Indonesian Energy Companies, lobbying activities informally done by Indonesian automotive industry so they are not listed in the sustainability reports.

In shareholder focused category, the most widely discussed indicators are the rollout of CSR in terms of organization and awareness and training for CSR. Meanwhile, there are 4 indicators that not discussed by 2 cement companies in Indonesia: independence of directors, compensation and remuneration schemes, voting rights, and anti-takeover devices. And reporting process indicator is only discussed by one cement company in Indonesia. Shareholder focused category becomes the most rarely discussed compared to other categories by 2 cement companies in Indonesia

In supplier focused category, the most widely discussed indicators are outsourcing policy, and involvement in labor rights violations of firm contractors. Similar with Indonesian Energy Companies, Indonesian cement companies considered the policy about involvement in labor rights violations of firm contractors is mainly part of Ministry of Labor's responsibility.

In environment focused category, all indicators are widely discussed in the sustainability of energy companies in Indonesia. This reflects the similar awareness between Indonesian cement and energy companies in making sustainability reports that focus on aspects of the environment.

In employee focused category, almost all the indicators are discussed in the sustainability reports of energy companies in Indonesia, except work time organization and management and industrial relations.

In general, sustainability reports of energy companies and cement companies in Indonesia have the similar focus on customer focused, community focused, an environment focused, and employee focused categories.

\section{CONCLUSION}

This research develops CSP measurement consisting of 38 indicators that categorized into six categories, which are customer focused, community focused, shareholder focused, supplier focused, environment focused, and employee focused. There are 5 indicators for customer focused, 5 indicators for community focused, 7 indicators for shareholder focused, 5 indicators for supplier focused, 7 indicators for environment focused, and 9 indicators for employee focused.

This research identifies that the most discussed indicators in Sustainability Reports of energy companies in Indonesia are in environment focused category and the least discussed indicators are in supplier focused category. The most discussed indicators in environment focused category is assessment and compliance procedures. The least discussed indicators in supplier focused category are outsorcing policy and involvement in labor rights violations of firm contractors.

Based on observations in the sustainability reports of Indonesian energy companies, there are findings related to production resources indicator that not covered by the current CSP Indicators. However, the use production resources as a CSP indicator need to be customized for some industries.

The result of this study can be improve by doing more exploration directly to the company. This is done to confirm the secondary data, reveal the unreported situation, and enrich the CSP indicators so it can be more contextual.

\section{REFERENCES}

[1] Ministry of Finance. (2016). APBN 2016. [Online]. Available: www.kemenkeu.go.id/APBN2016

[2] Asian Development Bank, "Achieving universal electricity access in Indonesia," Asian Development Bank, Mandaluyong, 2016.

[3] World Commission on Environment and Development, "World commission on environment and development: Our common future," World Commission on Environment and Development, 1987. 
[4] M. Kaptein and J. Wempe, "The ethics report: A means of sharing responsibility," Business Ethics, vol. 7, no. 3, pp. 131-139, 2002.

[5] A. Focacci, "Corporate social responsibility performance assessment by using a linear combination of key indicators," Int. J. Business Governance and Ethics, vol. 6, no. 2, pp. 183-202, 2011.

[6] M. van Marrewijk, "Concepts and definitions of CSR and corporate sustainability: Between agency and communion," Journal of Business Ethics, vol. 44, no. 2, pp. 95-105, 2003.

[7] T. E. Graedel and B. R. Allenby, Industrial Ecology, 1st ed., Englewood Cliffs: Prentice Hall, 1995.

[8] U. Bititci, P. Garengo, V. Dörfler and S. Nudurupati, "Performance measurement: Challenges for tomorrow," International Journal of Management Reviews, vol. 14, no. 3, pp. 305-327, 2012.

[9] I. Ducassy and S. Montandrau, "Corporate social performance, ownership structure, and corporate governance in France," Research in International Business and Finance, vol. 34, pp. 383-396, 2015.

[10] M. Orlitzky, C. Louche, J.-P. Gond and W. Chapple, "Unpacking the drivers of corporate social performance: a multilevel, multistakeholder, and multimethod analysis," Journal of Business Ethics, pp. 1-20, 2015.

[11] M. Dočekalová, "Construction of corporate social performance indicators for Czech manufacturing industry," Acta Universitatis Agriculturae et Silviculturae Mendelianae Brunensis, vol. LXI, no. 2, p. 309-315, 2013.

[12] E.-M. Hammann, A. Habisch and H. Pechlaner, "Values that create value: socially responsible business practices in SMEs - empirical evidence from German companies," Business Ethics: A European Review, vol. 18, no. 1, pp. 37-51, 2009.

[13] D. B. Turban and D. W. Greening, "Corporate social performance and organizational attractiveness to prospective employees," Academy of Management Journal, vol. 40, no. 3, pp. 658-672, 1997.

[14] T. Ilhan-Nas, E. Koparan and T. Okan, "The effects of the CSR isomorphism on both CSP and CFP," Journal of Asia Business Studies, vol. 9, no. 3, pp. 251-272, 2015.

[15] J. Gharajedaghi, Systems Thinking: Managing Chaos and Complexity, California: Elsevier, 2006.

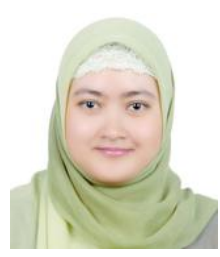

Amelia Kurniawati is a lecturer at the Department of Industrial Engineering, Telkom University in Bandung, Indonesia. She received a master degree from Bandung Institute of Technology Indonesia in 2009. She is now a PhD Student at Bandung Institute of Technology Indonesia. Her current research interest is in the area of knowledge management and organizational performance.

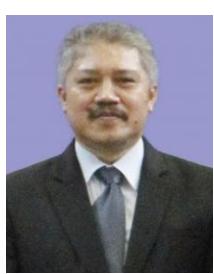

TMA Ari Samadhi is an associate professor at Department of Industrial Engineering, Bandung Institute of Technology in Bandung, Indonesia. He received the doctoral degree from University of New South Wales, Australia in Production Network field. His current research interest is in technology and manufacturing system field.

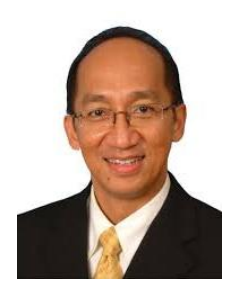

Iwan Inrawan Wiratmadja is an associate professor at the Department of Industrial Engineering, Bandung Institute of Technology in Bandung, Indonesia. He received the doctoral degree from Ecole Superieure des Affaire-University Pierre Mendes France, Grenoble in 1995 in management of technology field. His current research interest is in technology and knowledge management field.

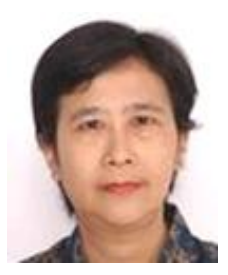

Indryati Suanryo is an associate professor at the Department of Industrial Engineering, Bandung Institute of Technology in Bandung, Indonesia. She received the doctoral degree from Bandung Institute of Technology, Indonesia in 2005. Her current research interest is in Human resource management.

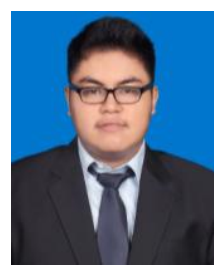

University.

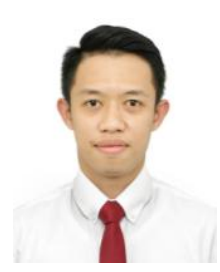

Rayinda Pramuditya Soesanto is a lecturer at the Department of Industrial Engineering, Telkom University in Bandung, Indonesia. He received his master degree of industrial and engineering management in 2017. His research interests are in the area of information system, decision support system and product development. $\mathrm{He}$ is the member of e-business and technology group expertise at Telkom

Fadel Muhammad was a student at Department of Information System, Telkom University, Bandung. He received his Bachelor of Information System from Telkom University in 2013. His research interests are in the area of knowledge management. 